\title{
Inactivation of Coronaviruses in food industry: The use of inorganic and organic disinfectants, ozone, and UV radiation
}

\author{
Roberto Quevedo-león ${ }^{1, *} \mathbb{D}^{\mathbb{D}}$; José Miguel Bastías-Montes ${ }^{2} \mathbb{D}$; Teófilo Espinoza-Tellez ${ }^{1}$; \\ Betty Ronceros $^{1} \mathbb{I D}^{\text {; I Iván Balic }}{ }^{1 \mathbb{D}}$; Ociel Muñoz ${ }^{3} \mathbb{D}$ \\ 1 Departamento de Acuicultura y Recursos Agroalimentarios, Programa Fitogen, Universidad de Los Lagos, Av. \\ Alberto Fuchslocher 1305, Región de los Lagos, Osorno, Chile. \\ 2 Departamento de Ingeniería en Alimentos, Universidad del Bío-Bío, Av. Andres Bello 720, Chillán, Chile. \\ 3 Instituto de Ciencia y Tecnología de los Alimentos, Facultad de Ciencias Agrarias y Alimentarias, Universidad Austral \\ de Chile, Campus Isla Teja, Valdivia, Región de los Ríos, Chile.
}

Received May 14, 2020. Accepted May 22, 2020.

\begin{abstract}
Currently there is a worldwide pandemic due to Covid-19, which has caused a great impact on humanity in social, economic, psychological aspects and unfortunately on health. Due to the risk that food can also be a medium to cause virus diseases, the procedures in the food industry safety programs must be revised; and, to be more specific, to disinfect Covid-19. Some effective disinfectants that have been proved to inactivate the coronavirus are: chlorine dioxide, sodium hypochlorite, quaternary compound, ozone and UV-C (shortwave ultraviolet light). In this review, some treatments used to inactivate a virus, with an emphasis to the coronavirus family, and other influenza viruses, are reported. It has been concluded that the coronavirus could be inactivated using free chlorine solutions at $30 \mathrm{mg} / \mathrm{L}$, sodium hypochlorite $0.25 \%$, or Chlorine Dioxide ( $99 \%$ purity) diluted at $1 / 2.5$ relation. Also, alcohol is an effective disinfectant at concentrations of 62 to $71 \%$ of ethanol. With respect to the use of the quaternary compound, it can be used at concentrations of $0.10 \%$. Ozone is another promising disinfectant to inactivate the coronavirus and Covid-19. Doses of ozone between 10 to $20 \mathrm{ppm}$ for 10 to 15 minutes are recommended to inactivate the coronavirus with $3.5 \log _{10}$ reductions. However, a warning should be reported to the use of high doses of exposure because it can be a risk to human health. UV-C can inactivate the coronavirus at a value of $67 \mathrm{~J} / \mathrm{m}^{2}$ by 1 to 30 minutes of exposure.
\end{abstract}

Keywords: Covid-19; SARS-CoV; Hypochlorite; Ozone; ultraviolet light; food safety; UV-C Radiation.

\section{Introduction}

Viruses, unlike cellular bacteria, consist only of a single protein shell (called a capsid), which contains within its RNA segments that are instructed to invade a host cell. They are generally much smaller than bacteria, about a few nanometers in size (one nanometer (" $\mathrm{nm}$ ") is equivalent to 10-9 m) (Darnell and Taylor, 2006). Certain viruses are known to cause health problems for humans; and since they are not strictly cellular organisms, most antibiotics do not usually inactivate them. It is required in those cases to produce specific antibodies (vaccines) in order to be inactivated (Bodmer et al., 2018).
Viruses, when they do not have a host, can usually be present for a time on all kinds of surfaces; these include both biological and non-biological materials (plastics, metals, air, among others). This obviously also includes unprocessed foods, which often carry the virus on their surfaces (Hirneisen et al., 2011; Mullis et al., 2012a). For example, it has already been determined that viruses are often present in fruits and vegetables when they have been exposed to unsanitary environments. Presence of human viruses in treated sewage has been detected at concentrations of $10^{4}$ to $10^{5}$ virus particles/L (Hellmér et al., 2014; Wang et al., 2018; Wolf et al., 2019). 
Many viruses inhabit animal species, which can be consumed and produce fatal diseases to the population. An example is a recent specific case of SARS-CoV-2 virus, also called Covid-19 (a virus belonging to the coronavirus family). There is reasonable evidence that it infected humans from the consumption of animal species such as bats ( $\mathrm{Li}$ et al., 2020; Menachery et al., 2020; Yuan et al., 2020). Consumption of these species may have caused a mutation of the virus, possibly because they were consumed without proper treatment. This is not the only case where food consumption may have caused the spread of a virus in humans, e.g. viruses are known to exist in pigs (Leopardi et al., 2020; Zhou et al., 2019; Zhu et al., 2019), dromedary (Gossner et al., 2016), alpacas (Crossley et al., 2010) and avian products (Chumpolbanchorn et al., 2006), among others. In the case of the avian influenza virus (spherical virus with a size between 80 $120 \mathrm{~nm}$ ), it caused a zoonotic disease in Southeast Asia and throughout the world. In Southeast Asia, more than 60 people have died from the disease since the first case in Hong Kong was reported in 1997. In Thailand, there were 13 deaths in 21 cases reported from December 2003 to November 2005 (Kim, 2018; McDevitt et al., 2012).

Currently, there is a worldwide pandemic due to the Covid-19 coronavirus, which has caused a great impact on humanity in social, economic, and psychological aspects and unfortunately on health with an average mortality rate of $2.5 \%$ (Kitajima et al., 2020). The sources of contamination have generally been human-to-human contact (van Doremalen et al., 2018); but, there are other possible sources of contamination. For example, contaminate surfaces with the virus including biological materials such as food. No studies have been reported to date to efficiently disinfect Covid-19. Safe treatments to disinfect using inorganic or organic components should be investigated. The population is currently exposed to contamination from food that has been handled by viruspositive people, or from the use of contaminated water in cleaning (Mullis et al., 2012b). In fact, Covid-19 can be active for up to 9 days on surfaces that maintain its high infection rate and rapid spread (more rapid than SARS-CoV) (Kowalski et al., 2020).

In the disinfection of fruits and vegetables, inorganic chemical components such as hypochlorite and quaternary ammoniums are usually used; as well as organic stems such as, ethanol, propanol, among other components. Many of them have demonstrated their effectiveness in the elimination of viruses in food. With regard to the inactivation of Covid-19, there are no studies on the recommended doses of these disinfectants to inactivate it; however, effective doses have been reported for viruses of the same family of the coronavirus (MERS, SARS-CoV, and Murine Coronavirus). The similarity genomic structure of Covid-19 with respect to members of the same family is very appreciable (Henwood, 2020; Schmidt et al., 2005; Woo et al., 2010). For that, the disinfection doses tested for other members of its own family are expected to have a similar effect.

The indiscriminate use of chemical disinfectants can also have an impact on the environment and people. Waste is produced that must be treated before being disposed and it also can be toxic to human health. The World Health Organization (WHO) has recommended caution in the use of disinfection methods because the population may informally use indiscriminate concentrations of disinfectants that are not suitable for eliminating coronaviruses (including Covid-19); they may lead to an increase in cases of disinfectant poisoning.

This review presents a summary of the scientific evidence on the treatment of food with inorganic or organic disinfectants, which have been used to specifically inactivate viruses of the coronavirus family (MERS, SAR-CoV, Murino coronavirus); as well as other viruses, such as $\mathrm{HnNn}$ influenza, swine influenza or avian influenza. Although, there are no specific studies for the Covid-19 virus in the international scientific community, this review may be useful to the industry in the search for disinfectants and their most recommended doses to treat viruses in the Covid-19 family - the coronaviruses (COVs). The present work aims to show the use of different types of disinfectants and their dosages, in the food industry; as well as, to discuss the advantages and disadvantages of each disinfectant with respect to environmental sustainability.

\section{Coronaviruses classification}

The ability of viruses to infect the human host is an important reason that the WHO makes top list of emerging diseases likely to cause major epidemics. The list includes severe acute respiratory syndrome coronavirus (SARS-CoV), and recently Covid-19 which caused the current pandemic (Gravemann et al., 2018; Mullis et al., 2012b). SARS-CoV viruses belong to the Orthocoronavirinae species, Coronaviridae family, and Nidovirales order; they are characterized by being large, and enveloped single-stranded RNA. Based on genotypic and serologic characterization, CoVs can be subdivided into the genera Alphacorona- 
virus, Betacoronavirus, Gammacoronavirus and Deltacoronavirus (Crossley et al., 2010). CoVs are defined as enveloped viruses of 120-160 $\mathrm{nm}$ in diameter with a crown-like appearance. The name "coronavirus" is derived from the Greek "кориंvа", meaning crown and containing the largest genomes (26.4 to $31.7 \mathrm{~kb}$ ) among all known RNA viruses, with $\mathbf{G}+\mathbf{C}$ contents varying from $32 \%$ to 43\% (Henwood, 2020). The differences between genera are by the genome organization, Alpha-, Beta-, Gamma and Delta prototypes (Decaro, 2011; Poletti and Mavilio, 2017). In Table 1, common viruses for genera Alphacoronavirus, and their respective host, are listed.

Due to the current pandemic 2020, the most important virus to be monitored by the food industry is the CoVs, mainly the SARS-CoV and Covid-19. They are very contagious, and they are deadly to humans. SARS-CoV and Covid-19 are classified in the genera Betacoronavirus, due to that they show a beta prototype in their genome structure.

\subsection{Risk of Coronavirus and influenza virus in food}

Pre-harvest contamination for foodborne viruses can occur through a variety of agents, including animal feces, manures, soil, irrigation water, animals, and human handling. Problems of contamination are magnified by potential countrywide distribution. Postharvest processing of produce can involve spraying, washing, or immersion into water with disinfectants; however, disinfectants, including chlorine, have varying effects on viruses and produce harmful by-products pose a concern (Hirneisen et al., 2011).

Transmission of CoVs in humans is generally airborne or by person-to-person contact through droplets of saliva, sneezes, coughs, and secretions that can contaminate hands and surfaces. However, currently the food industry is facing numerous uncertainties about of the presence of Covid-19 in food production, distribution, marketing, home preparation of meals (Oliveira et al., 2020) or in the generation of wastewater (Kitajima et al., 2020). Coronavirus infections have a significant economic impact on agriculture, human health, and social impact in the word. In the early 1980's the bovine coronavirus (BCoV) began to heavily impact food agriculture, due to the apparition of viral gastroenteritis in cattle (Clark et al., 1998). In fact, BCoV had a major impact on the cattle industry, with economic losses occurring due to morbidity, mortality, treatment and prevention costs, loss of production, and reduced carcass value (Boileau and Kapil, 2010; Fulton et al., 2011). Therefore, presence of BCoV in the bovine or calves can be a source of virus contamination in humans when they are consuming beef as a food. As well as fruits (Brie et al., 2018) and vegetables (Mullis et al., 2012b) can be a food source of CoVs contamination. The need to adopt measures to reduce the risk of a breakdown in food supply services is required. Recently WHO reported that the Hepatitis E virus, Highly Avian influenza, $\mathrm{H}_{5} \mathrm{~N}_{1}$ influenza virus, SARS$\mathrm{CoV}$ and Nipah virus, as pathogenic having the potential for foodborne transmission. Initial foodborne transmission is a route to enter the human population, which can then shift and spread through human-to-human transmission.

The generation of studies for prevention of CoVs infections due to food contamination requires adherence to the countries in the world and by programmers who consume. Because a vaccine to inactivate CoVs in humans is not yet available, the food sanitization programs in the entire world should be reformulated to decrease the risk of infections by the presence of CoVs in food. Fast protocols to prevent the possibility of contamination of viruses (i.e. by coronaviruses) from food are to be researched.

Table 1

Some Genera of Coronaviruses

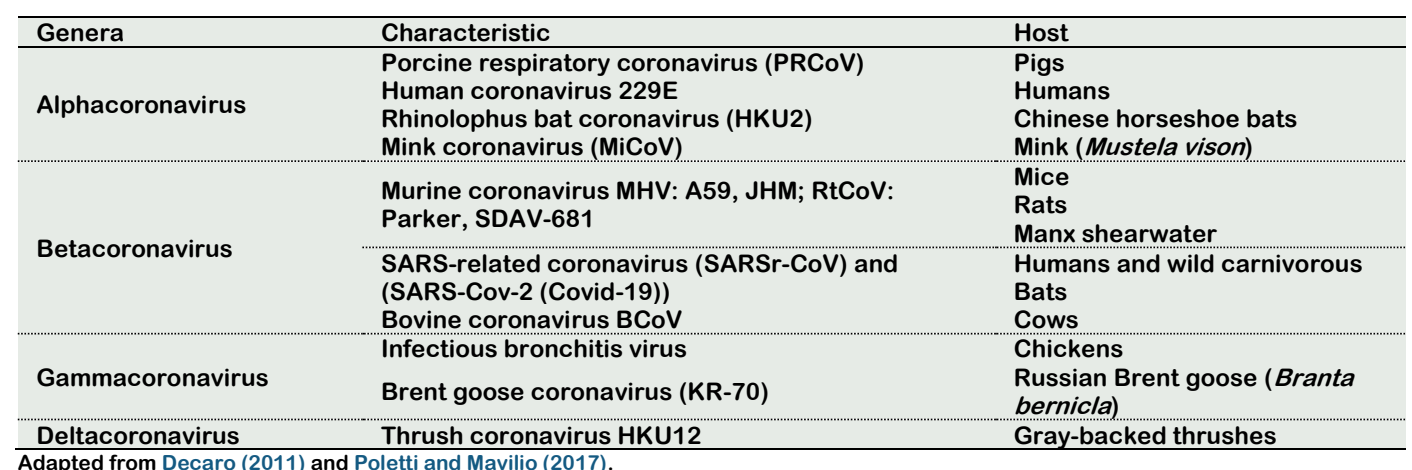




\section{Inactivation of CoVs and influenza virus, using common disinfectants}

Fruits and vegetables are heavily consumed and have good nutritional value. The perishable nature of these products, which determines its fast consumption and also the number of associated outbreaks, identifies the importance of applying efficient decontamination strategies (Mullis et al., 2012b). They can be treatments with heat to destroy the viruses. Another alternative has been the use of chemical disinfectants, in the case of fresh food.

\subsection{Use of free chlorine and derivate}

Free chlorine readily penetrates the lipid membrane of microorganism to react with proteins in the nucleocapsid and polymer-ase complex (Ye and Wigginton, 2018). In the case of a virus, free chlorine damaged viral capsids, allowing free chlorine access to vi-ral RNA to damage viral genomes and cause it to lose its ability to bind to its host recep-tors (Fuzawa et al., 2019). Chlorine can be used in a gas form (chlorine dioxide) or liq-uid form (hypochlorite). Chlorine dioxide is regarded as a broad-spectrum disinfectant with strong inhibitory effects on microbes and parasites, and is an efficient agent and potently suppressed porcine reproductive and respiratory syndrome virus infection in vitro (Kingsley et al., 2018; Zhu et al., 2019). Chlorine dioxide $\left(\mathrm{ClO}_{2}\right)$ is commonly applied to food or irrigation water which has the advantage of not forming organo-halogen byproducts, and it is a more powerful oxidant than sodium hypochlorite (Lopez-Galvez et al., 2018).

Liquid Sodium hypochlorite $(\mathrm{NaOCl})$ is another chlorine compound used as a disinfectant. It has an effective antimicrobial activity, a broad bacterial range, and creates a significant reduction in endotoxins levels (Neelakantan et al., 2019). However, several studies have demonstrated that complete bacterial elimination cannot be achieved consistently with any of the current disinfection protocols (Silva et al., 2020; Siqueira et al., 2018). It is important to note that chlorination of water that contains amino acids have been shown to produce toxic cyanogen chloride. Dissolved organic nitrogen substances can also react with chlorine to give organo-chloramines. Peptides in water are of greater concern than free amino acids because chlorinated products of peptides are relatively more stable than the chlorinated derivate of amino acids (Sharma and Graham, 2010).

\subsection{Use of Alcohol}

Most alcohols used in disinfection are etha-nol and isopropyl alcohol, both usually at a concentration of $70 \%$; for example, the transmissible gastroenteritis virus (TGEV) was reduced $4.5 \log _{10}$ by ethanol in the suspension test, over 5 minutes. Similarly, using QCT-2 and organic load, ethanol was re-duced by at least $3 \log _{10}$ over the course of 5 minutes (Schmidt et al., 2005). Ethanol is widely used in hand rubs, gels, and foams for hand hygiene in healthcare settings. In fact, The WHO has even listed ethanol at $80 \%(\mathrm{v} / \mathrm{v})$ as an essential medicine in the cat-egory 'alcohol-based hand rubs' and since 1994, the US Food and Drug Administration considers ethanol between $60 \%$ and $95 \%$ as generally safe and effective (Kampf, 2018). It has been noted that coronaviruses, such as $0.05 \%$ to $0.2 \%$ benzalkonium chloride or $0.02 \%$ chlorhexidine digluconate were less effective. Coronaviruses, e.g. severe acute respiratory syndrome (SARS) and Middle East respiratory syndrome (MERS), can be inactivated by $70 \%$ ethanol and $0.1 \%$ sodium hypochlorite; for that, it is believed that Covid-19 would be similarly affected (Kampf et al., 2020).

\subsection{Use of quaternary ammonium}

Quaternary ammonium cations are another type of disinfectant that have spermicidal and antimicrobial activity and inactivation of encapsulated viruses, especially those containing long alkyl chains (Mizzen et al., 1985). Examples are benzalkonium chloride, benzethonium chloride, methylbenzetho-nium chloride, cetalconium chloride, cetylpyridinium chloride, cetrimonium, ce-trimide, tetraethylammonium bromide, didecyldimethylammonium chloride and domiphene bromide. Alam et al. (2018) showed that the quaternary ammonium (di-luted at 1:500 (QACX500)) inactivated the avian influenza on steel and plastic carriers after 60 minutes of exposition. In Table 2, the applications of common disinfectants to in-activate common coronaviruses and influ-enza viruses are shown.

\subsection{Use of Ozone $\left(\mathrm{O}_{3}\right)$}

Ozone is a powerful antimicrobial agent that is suitable for application in food in the gaseous and aqueous states. It is one of the most effective sanitizers known, yet it leaves no hazardous residues on food or food-contact surfaces. The precursors for industrial production of ozone (that is, $\mathrm{O}_{2}$ or $\mathrm{HO}$ ) are abundant and inexhaustible. Ozone treatment requires no heat and hence saves energy (Hirneisen et al., 2011; Khadre et al., 2001; Wang et al., 2018). 
Table 2

Common virus and its corresponding treatment with disinfectants

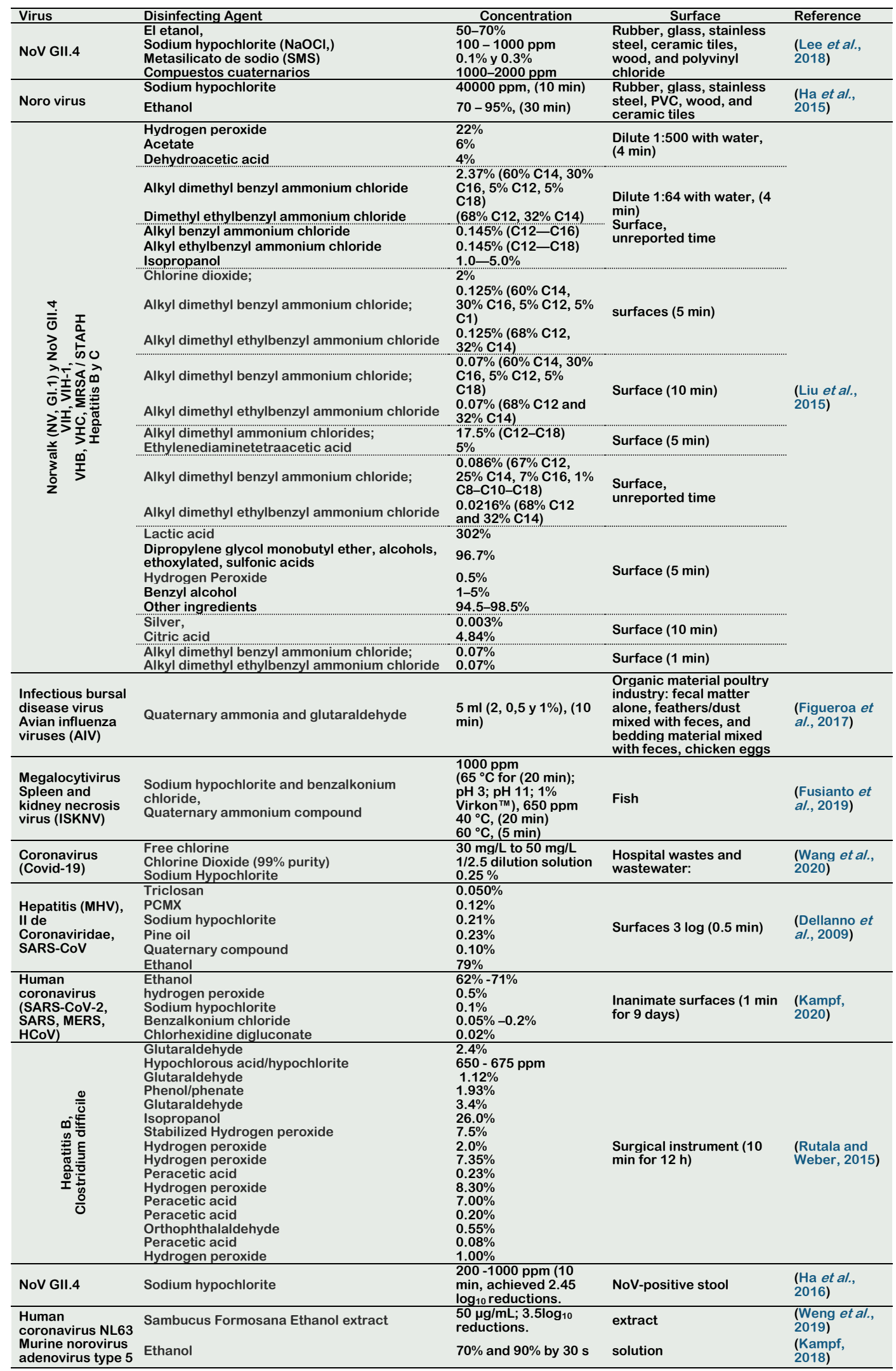


Gaseous ozone has a residual effect, for example its half-life based on temperature in Gaseous is at 8 days at $-25^{\circ} \mathrm{C}, 3$ days at $20^{\circ} \mathrm{C}$ and 1.5 hours at $120^{\circ} \mathrm{C}$. In aqueous ozone it is at 30 minutes at $15^{\circ} \mathrm{C}, 20$ minutes at $20^{\circ} \mathrm{C}$ and 15 minutes at $25^{\circ} \mathrm{C}$ (Miller et al., 2013). Aqueous ozone has been used to decontaminate poultry meat (lanni et al., 2019), salmon (Crowe et al., 2012), apples (Camargo et al., 2019), strawberries (Nayak et al., 2020), and others foods (Mahapatra et al., 2005). Hirneisen et al. (2011) tested ozone for the processing of lettuce and reported that bubbling ozone reduced counts of natural microflora in the range of 2 to $3 \log _{10}$. Also, it has been used to prevent mold growth on cheese and inactivate airborne molds in cheese ripening and storage facilities. Ozone treatment has also been found to be a promising method for reducing the concentrations of pollutants in dairy wastewaters (Varga and Szigeti, 2016). In Table 3, treatments to inactivate coronaviruses and influenza virus by $0_{3}$ is showed.

Ozone is a strong oxidative compound both in its gaseous form and when dissolved in water and, because of this, is known to be an efficient disinfectant for inactivating even the chemically resistant. Its oxidative potential is higher than that of hydrogen peroxide and hypochlorite (Mahfoudh et al., 2010). However, concentration levels of $\mathrm{O}_{3}$ and residence times must be controlled, because it is toxic in humans at high doses. One-hour exposure to ozone concentrations of $2,4,15$, and $95 \mathrm{ppm}$ induces symptomatic, irritant, toxic, and irreversible lethal effects in humans, respectively. In fact, the human lung is the primary target of ozone gas (Khadre et al., 2001). The Food and Drug Administration (FDA) requires a concentration limit exposure of $0.05 \mathrm{ppm}$ during 8 hours, Occupational Safety and Health Administration (OSHA) requires a concentration limit exposure of 0.10 ppm during 8 hours, National Institute of Occupational Safety and Health (NIOSH) recommends an upper limit of $0.10 \mathrm{ppm}$, not to be exceeded at any time, Environmental Protection Agency (EPA) requires a concentration limit exposure of $0.08 \mathrm{ppm}$ during 8 hours (Miller et al., 2013).

\subsection{Use of ultraviolet light ("UV") as virus disinfectant}

Ultraviolet light can be an effective disinfectant for decontaminating virus surfaces, including the SARS-CoV virus. It is possibly because UV inducing photo dimers in the genomes of microorganisms structure (Darnell et al., 2004). Ultraviolet light has been demonstrated to be capable of destroying viruses, bacteria and fungi in hundreds of laboratory studies (McDevitt et al., 2012). Although SARS-CoV-2 virus has not yet been specifically tested for its ultraviolet susceptibility, other tests on related coronaviruses, including the SARS coronavirus, have concluded that they are highly susceptible to ultraviolet inactivation (Kowalski et al., 2020). UV light is divided into three classifications: UV-A (320 - $400 \mathrm{~nm})$, UV-B (280 - $320 \mathrm{~nm})$, and UV-C (200- $280 \mathrm{~nm})$. UV-A is weakly absorbed by DNA and RNA, and is much less effective than UV-C and UV-B. Duan et al. (2003) found that irradiation with ultraviolet light for 60 minutes on several coronaviruses in culture medium resulted in undetectable levels of viral infectivity.

$U V$ is uniquely vulnerable to the virus at wavelengths near to $253.7 \mathrm{~nm}$ (UV-C range). This is because the maximum absorption wavelength of a DNA molecule is around to $260 \mathrm{~nm}$. UV-A and UV-B require more exposure time to be effective against viruses. Also, airborne microorganisms are much more susceptible to UV damage than those suspended in a liquid suspension; additionally, the type of the microorganism, affected the efficacy of UV-C. For example, the UV-C dose between fungal spores and bacterial cells is as high as 80 times (Tseng and Li, 2005).

Similarly, to the other disinfectants, human exposure to high levels of UV-C irradiation is dangerous to their health. Overexposure to ultraviolet (UV) radiation is the main modifiable risk factor for skin cancer (Lehmann et al., 2019). Exposure to UV-C is not recommended for humans at levels of 2.5 $\mathrm{J} / \mathrm{m}^{2}$ by 10 to 15 minutes can produce erythema (redness of the skin or mucous membranes) (McKenzie and Lucas, 2018). The UV-A dosage was set to levels calculated safe for human occupation at maximum of $10 \mathrm{~W} \mathrm{~m}^{2}$ for 8 hours, at eye level (Brons et al., 2020). In Table 4, some treatment to inactivate coronaviruses and influenza virus by UV are showed.

From the Tables 2 to 4 , we can observe that doses to inactive CoVs can vary depending on the sample conditions and the raw materials used in the experiments. According to Table 2, CoVs could be inactivated using free chlorine solutions at $30 \mathrm{mg} / \mathrm{L}$, sodium hypochlorite 0.25 $\%$, or Chlorine Dioxide ( $99 \%$ purity) diluted at $1 / 2.5$ relation (Wang et al., 2020). Also, alcohol is an effective disinfectant of CoVs, it can inactivate at concentrations of 62 to $71 \%$ of ethanol (Kampf, 2018; Kampf et al., 2020). With respect to the use of the Quaternary compound, it can be used at concentrations of $0.10 \%$ (Dellanno et al., 2009). In addition, the use of the Sambucus Formosana ethanol extracts, at $50 \mu \mathrm{g} / \mathrm{mL}$, can be used to inactivated CoVs (Weng et al., 2019). 
Table 3

Common virus and its corresponding treatment with ozone

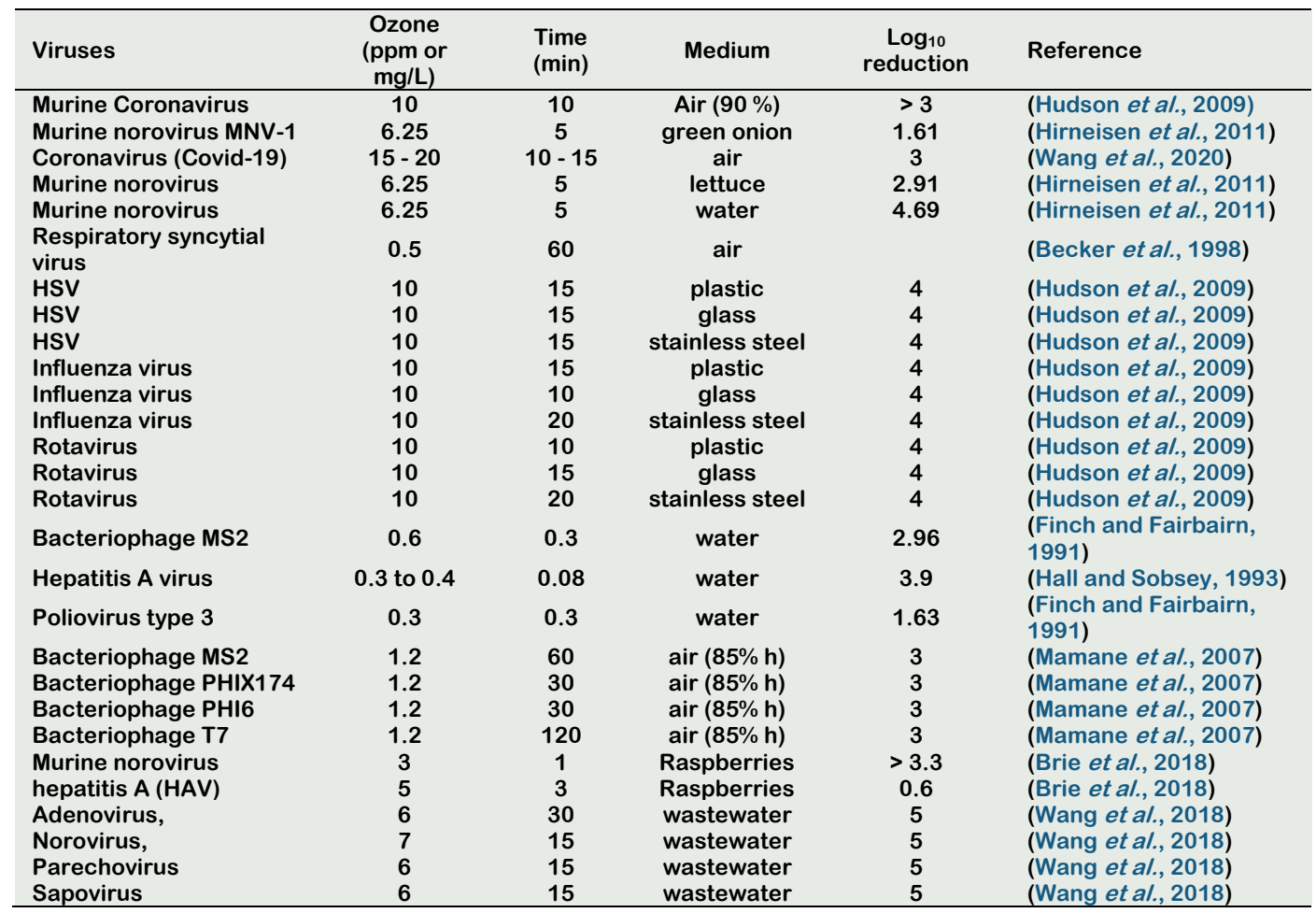

Table 4

Common virus and its corresponding treatment with UV

\begin{tabular}{|c|c|c|c|c|c|}
\hline Viruses & $\begin{array}{l}\text { UV } \\
\text { dose }\end{array}$ & $\begin{array}{l}\text { Time } \\
(\min )\end{array}$ & Medium & $\begin{array}{l}\log _{10} \\
\text { reduction }\end{array}$ & Reference \\
\hline $\begin{array}{l}\text { SARS CoV } \\
\text { Urbanus }\end{array}$ & $241 \mathrm{~J} / \mathrm{m}^{2}$ & 1 & air & 3 & (Kowalski et al., 2020) \\
\hline Coronavirus & $7 \mathrm{~J} / \mathrm{m}^{2}$ & 1 & air & 3 & (Walker and Ko, 2007) \\
\hline SARS CoV & $40.16 \mathrm{~J} / \mathrm{m}^{2}$ & 6 & air & 3 & (Darnell et al., 2004) \\
\hline Canine coronavirus & $29 \mathrm{~J} / \mathrm{m}^{2}$ & 1 & air & 3 & (Kowalski et al., 2020) \\
\hline SARS CoV & $1.7 \mathrm{~J} / \mathrm{s} \mathrm{m}^{2}$ & 20 & plasma & $>3.4$ & (Eickmann et al., 2020) \\
\hline Murine Coronavirus & $29 \mathrm{~J} / \mathrm{m}^{2}$ & 1 & air & 3 & (Kowalski et al., 2020) \\
\hline $\begin{array}{l}\text { SARS CoV } \\
\text { Hanoi }\end{array}$ & $134 \mathrm{~J} / \mathrm{m}^{2}$ & 1 & air & 3 & (Kowalski et al., 2020) \\
\hline Nipah virus & $1.7 \mathrm{~J} / \mathrm{s} \mathrm{m}^{2}$ & 20 & plasma & $>4.3$ & (Eickmann et al., 2020) \\
\hline $\begin{array}{l}\text { Haemorrhagic fever } \\
\text { virus }\end{array}$ & $1.7 \mathrm{~J} / \mathrm{s} / \mathrm{m}^{2}$ & 20 & plasma & $>2.2$ & (Eickmann et al., 2020) \\
\hline Berne Virus & $7 \mathrm{~J} / \mathrm{m}^{2}$ & 1 & air & 3 & (Kowalski et al., 2020) \\
\hline T7 virus & $20 \mathrm{~J} / \mathrm{s} \mathrm{m^{2 }}$ & 0.017 & air $55 \%$ RH & 3 & (Tseng and Li, 2005) \\
\hline Phi6 virus & $17.7 \mathrm{~J} / \mathrm{s} \mathrm{m}^{2}$ & 0.017 & air $55 \%$ RH & 3 & (Tseng and Li, 2005) \\
\hline SARS CoVP9 & $1 \mathrm{~J} / \mathrm{s} \mathrm{m}^{2}$ & 30 & & & (Duan et al., 2003) \\
\hline MS2 virus & $9 \mathrm{~J} / \mathrm{s} \mathrm{m^{2 }}$ & 0.0107 & air $55 \% \mathrm{RH}$ & 3 & (Tseng and Li, 2005) \\
\hline PhiX174 virus & $10.3 \mathrm{~J} / \mathrm{s} \mathrm{m}^{2}$ & 0.017 & air $55 \%$ RH & 3 & (Tseng and Li, 2005) \\
\hline $\begin{array}{l}\text { Avian influenza virus } \\
\text { aiv } H_{1} N_{1}\end{array}$ & $15 \mathrm{~J} / \mathrm{m}^{2}$ & 15 & air & 2 & (McDevitt et al., 2012) \\
\hline $\begin{array}{l}\text { Avian influenza virus } \\
\text { aiv } \mathrm{H}_{7} \mathrm{~N}_{1}\end{array}$ & $\begin{array}{l}0.9 \mathrm{~J} / \mathrm{m}^{2} \\
\text { UVB }\end{array}$ & 158 & air & 1 & (Sutton et al., 2013) \\
\hline $\begin{array}{l}\text { Avian influenza virus } \\
\text { aiv } \mathrm{H}_{5} \mathrm{~N}_{1}\end{array}$ & $\begin{array}{l}0.9 \mathrm{~J} / \mathrm{m}^{2} \\
\text { UVB }\end{array}$ & 167 & air & 1 & (Sutton et al., 2013) \\
\hline Influenza viruses & $23 \mathrm{~J} / \mathrm{m}^{2}$ & 20 & air & 3 & (Sutton et al., 2013) \\
\hline
\end{tabular}


The use of Ozone is another promising disinfectant to inactivate CoVs and Covid-19. Doses of $0_{3}$ between 10 to $20 \mathrm{ppm}$ for times of 10 to 15 minutes are recommended to inactivate CoVs at $3.5 \log _{10}$ reductions. However, a warning should be reported for use of high doses and exposure because it can be a risk to human health (limited exposure to humans is $\mathbf{0 . 0 5}$ ppm for 8 hours).

From Table 4, ranges of UV-C dose, for inactive CoVs; is around $7-241 \mathrm{~J} / \mathrm{m}^{2}$, with a mean of $67 \mathrm{~J} / \mathrm{m}^{2}$. These values can be taken as an adequate representation of the ultraviolet susceptibility of the SARS-CoV- 2 (Covid-19) virus (Kowalski et al., 2020). With respect to the time exposure, UV-C shows ranges between 1 to $\mathbf{3 0}$ minutes of exposure. In early April, the SSLEEC member company Seoul Semiconductor, reported that a $99.9 \%$ of the Covid-19 sterilization can be reached at $\mathbf{3 0}$ seconds, using UV LED products.

\section{Conclusions}

Currently, there is a worldwide pandemic due to the Covid-19 coronavirus, which has caused a great impact on humanity in social, economic, psychological aspects and unfortunately on health. Due to the risk that food can also be a medium to cause a virus disease, the procedures in the food industry safety programs must be revised; and be more specific on how to disinfect for Covid19. Some effective disinfectants that have been proved to inactivate CoVs are chlorine dioxide, sodium hypochlorite, quaternary compound, ozone, and UV-C. Further research is still needed to explore new applications for these disinfectants and to best utilize the unique features of these sanitizers. For example, using the disinfectants in binary and/or ternary mixtures, to evaluate their synergies. Similarly, the efficiency of these mixtures in the inactivation of Covid19 should be explored.

\section{Acknowledgements}

We thank to the group: Área de Investigación Prioritaria (API-3), Sistema Agroalimentario Sostenible, Cambio Climático y Biodiversidad (Ulagos), for the financial support.

\section{ORCID}

R. Quevedo-León (D) https://orcid.org/0000-0001-8132-838X J.M. Bastías-Montes iD https://orcid.org/0000-0003-3387-6917

T. Espinoza-Tellez (D) https://orcid.org/0000-0003-1491-1051

B. Ronceros iD https://orcid.org/0000-0002-5851-0340

I. Balic iD https://orcid.org/0000-0003-3135-0647

O. Muñoz (iD) https://orcid.org/0000-0002-2445-4336

\section{References}

Alam, M.S.; Takahashi, S.; Ito, M.; et al. 2018. Virucidal Efficacy of a Quaternary Ammonium Compound with Food Additive-Grade Calcium Hydroxide Toward Avian Influenza Virus and Newcastle Disease Virus on Abiotic Carriers. Avian Diseases 62: 355-363.
Becker, S.; Soukup, J.M.; Reed, W.; et al. 1998. Effect of ozone on susceptibility to respiratory viral infection and virus-induced cytokine secretion. Environmental Toxicology and Pharmacology 6: 257-265.

Bodmer, B.S.; Fiedler, A.H.; Hanauer, J.R.H.; et al. 2018. Live-attenuated bivalent measles virus-derived vaccines targeting Middle East respiratory syndrome coronavirus induce robust and multifunctional T cell responses against both viruses in an appropriate mouse model. Virology 521: 99-107.

Boileau, M.J.; Kapil, S. 2010. Bovine coronavirus associated syndromes. Vet Clin North Am Food Anim Pract 26: 123-146.

Brie, A.; Boudaud, N.; Mssihid, A.; et al. 2018. Inactivation of murine norovirus and hepatitis A virus on fresh raspberries by gaseous ozone treatment. Food Microbiology 70: 1-6.

Brons, J.; Bierman, A.; White, R.; et al. 2020. An assessment of a hybrid lighting system that employs ultraviolet-A for mitigating healthcare-associated infections in a newborn intensive care unit. Lighting Research \& Technology 0: 1-18.

Camargo, J.A.; Murray, K.; Warriner, K.; et al. 2019. Characterization of efficacy and flow in a commercial scale forced air ozone reactor for decontamination of apples. LWT 113: 108325.

Chumpolbanchorn, K.; Suemanotham, N.; Siripara, N.; et al. 2006. The effect of temperature and UV light on infectivity of avian influenza virus (H5N1, Thai field strain) in chicken fecal manure. Southeast Asian J Trop Med Public Health 37: 102-105.

Clark, K.J.; Grant, P.G.; Sarr, A.B.; et al. 1998. An in vitro study of theaflavins extracted from black tea to neutralize bovine rotavirus and bovine coronavirus infections. Veterinary microbiology 63: 147-157.

Crossley, B.M.; Barr, B.C.; Magdesian; K.G.; et al. 2010. Identification of a novel coronavirus possibly associated with acute respiratory syndrome in alpacas (Vicugna pacos) in California, 2007. Journal of Veterinary Diagnostic Investigation 22: 94-97.

Crowe, K.M.; Skonberg, D.; Bushway, A.; et al. 2012. Application of ozone sprays as a strategy to improve the microbial safety and quality of salmon fillets. Food Control 25: 464-468.

Darnell, M.E.R.; Subbarao, K.; Feinstone, S.M.; et al. 2004. Inactivation of the coronavirus that induces severe acute respiratory syndrome, SARS-CoV. Journal of Virological Methods 121: 85-91.

Darnell, M.E.R.; Taylor, D.R. 2006. Evaluation of inactivation methods for severe acute respiratory syndrome coronavirus in noncellular blood products. Transfusion 46: 1770-1777.

Decaro, N. 2011. Alphacoronavirus $\ddagger$ In "The Springer Index of Viruses" (C. Tidona and G. Darai, eds.), pp. 371-383. Springer New York, New York, NY.

Dellanno, C.; Vega, Q.; Boesenberg, D. 2009. The antiviral action of common household disinfectants and antiseptics againstmurine hepatitis virus, a potential surrogate for SARS coronavirus. American Journal of Infection Control 37: 649-652.

Duan, S.M.; Zhao, X.S.; Wen, R.F.; et al. 2003. Stability of SARS coronavirus in human specimens and environment and its sensitivity to heating and UV irradiation. Biomedical and Environmental Sciences 16: $246-255$.

Figueroa, A.; Hauck, R.; Saldias-Rodriguez, J.; et al. 2017. Combination of quaternary ammonia and glutaraldehyde as a disinfectant against enveloped and non-enveloped viruses. Journal of Applied Poultry Research 26: 491-497.

Finch, G.R.; Fairbairn, N. 1991. Comparative inactivation of poliovirus type 3 and MS2 coliphage in demandfree phosphate buffer by using ozone. Appl Environ Microbiol 57: 3121-3126.

Fulton, R.W.; Step, D.L.; Wahrmund, J.; et al. 2011. Bovine coronavirus (BCV) infections in transported commingled beef cattle and sole-source ranch calves. Canadian Journal of Veterinary Research 75: 191-199. 
Fusianto, C.; Hick, P.; Becker, J. 2019. Stability of Infectious spleen and kidney necrosis virus and susceptibility to physical and chemical disinfectants. Aquaculture 506: 104-111.

Fuzawa, M.; Araud, E.; Li, J.R.; et al. 2019. Free Chlorine Disinfection Mechanisms of Rotaviruses and Human Norovirus Surrogate Tulane Virus Attached to Fresh Produce Surfaces. Environmental Science \& Technology 53: 11999-12006.

Gossner, C.; Danielson, N.; Gervelmeyer, A.; et al. 2016. Human-Dromedary Camel Interactions and the Risk of Acquiring Zoonotic Middle East Respiratory Syndrome Coronavirus Infection. Zoonoses and Public Health 63: 1-9.

Gravemann, U.; Eickmann, M.; Handke, W.; et al. 2018. SARS Coronavirus Is Efficiently Inactivated in Platelet Concentrates by UVC Light Using the Theraflex UV Platelets Technology. Transfusion 58: 240A-240A.

Ha, J.-H.; Choi, C.; Lee, H.-J.; et al. 2016. Efficacy of chemical disinfectant compounds against human norovirus. Food Control 59: 524-529.

Ha, J.-H.; Kim, M.; Choi, C.; et al. 2015. Recovery of structurally intact norovirus from food-contact surfaces. Food control 47: 564-568.

Hall, R.M.; Sobsey, M.D. 1993. Inactivation of Hepatitis a Virus and MS2 by Ozone and Ozone-Hydrogen Peroxide in Buffered Water. Water Science and Technology 27: 371-378.

Hellmér, M.; Paxéus, N.; Magnius, L.; et al. 2014. Detection of pathogenic viruses in sewage provided early warnings of hepatitis $A$ virus and norovirus outbreaks. Applied and environmental microbiology 80: 6771-6781.

Henwood, A.F. 2020. Coronavirus disinfection in histopathology. Journal of Histotechnology 2020: 1734718.

Hirneisen, K.A.; Markland, S.M.; Kniel, K.E. 2011. Ozone inactivation of norovirus surrogates on fresh produce. J Food Prot 74: 836-839.

Hudson, J.B.; Sharma, M.; Vimalanathan, S. 2009. Development of a Practical Method for Using Ozone Gas as a Virus Decontaminating Agent. Ozone: Science \& Engineering 31: 216-223.

lanni, A.; Grotta, L.; Martino, G. 2019. Feeding influences the oxidative stability of poultry meat treated with ozone. Asian-Australasian Journal of Animal Sciences 32: 874-880.

Kampf, G. 2018. Efficacy of ethanol against viruses in hand disinfection. Journal of Hospital Infection 98: 331-338.

Kampf, G. 2020. Potential role of inanimate surfaces for the spread of coronaviruses and their inactivation with disinfectant agents Infection Prevention in Practice 2: 1-5.

Kampf, G.; Todt, D.; Pfaender, S.; et al. 2020. Persistence of coronaviruses on inanimate surfaces and their inactivation with biocidal agents. J Hosp Infect 104: 246-251.

Khadre, M.A.; Yousef, A.E.; Kim, J.G. 2001 Microbiological aspects of ozone applications in food: A review. Journal of Food Science 66: 1242 1252.

Kim, T.-J. 2018. Prevention of Avian Influenza Virus by Ultraviolet Radiation and Prediction of Outbreak by Satellite Parameters. Journal of Biomedical Science and Engineering 11: 182-206.

Kingsley, D.H.; Perez-Perez, R.E.; Niemira, B.A.; et al. 2018. Evaluation of gaseous chlorine dioxide for the inactivation of Tulane virus on blueberries. International Journal of Food Microbiology 273: 28-32.

Kitajima, M.; Ahmed, W.; Bibby, K.; et al. 2020. SARSCoV-2 in wastewater: State of the knowledge and research needs. Science of The Total Environment 2020: 139076.

Kowalski, W.; Walsh, T.; Petraitis, V. 2020. 2020 CoVID19 Coronavirus Ultraviolet Susceptibility RG: 22566.

Lee, H.-M.; Yang, J.-S.; Yoon, S.-R.; et al. 2018. Immunomagnetic separation combined with RTQPCR for evaluating the effect of disinfectant treatments against norovirus on food contact surfaces. LWT 97: 83-86.

Lehmann, M.; Pfahlberg, A.B.; Sandmann, H.; et al. 2019. Public Health Messages Associated with Low UV Index Values Need Reconsideration. International Journal of Environmental Research and Public Health 16(12): 2067.

Leopardi, S.; Terregino, C.; De Benedictis, P. 2020. Silent circulation of coronaviruses in pigs. Veterinary Record 186: 323-323.

Li, X.; Song, Y.H.; Wong, G.; et al. 2020. Bat origin of a new human coronavirus: there and back again. Science China-Life Sciences 63: 461.

Liu, P.; Kim, M.; Schlesinger, D.; et al. 2015. Immunomagnetic separation combined with RTqPCR for determining the efficacy of disinfectants against human noroviruses. Journal of Infection and Public Health 8: 145-154.

Lopez-Galvez, F.; Randazzo, W.; Vasquez, A.; et al. 2018. Irrigating Lettuce with Wastewater Effluent: Does Disinfection with Chlorine Dioxide Inactivate Viruses? Journal of Environmental Quality 47: 11391145.

Mahapatra, A.; Muthukumarappan, K.; Julson, J. 2005. Applications of Ozone, Bacteriocins and Irradiation in Food Processing: A Review. Critical reviews in food science and nutrition 45: 447-61.

Mahfoudh, A.; Moisan, M.; Seguin, J.; et al. 2010. Inactivation of Vegetative and Sporulated Bacteria by Dry Gaseous Ozone. Ozone-Science \& Engineering 32: 180-198.

Mamane, H.; Shemer, H.; Linden, K.G. 2007. Inactivation of E. coli, B. subtilis spores, and MS2, T4, and T7 phage using UV/H2O2 advanced oxidation. J Hazard Mater 146: 479-486.

McDevitt, J.J.; Rudnick, S.N.; Radonovich, L.J. 2012. Aerosol susceptibility of influenza virus to UV-C light. Appl Environ Microbiol 78: 1666-1669.

McKenzie, R.0; Lucas, R. 2018. Reassessing Impacts of Extended Daily Exposure to Low Level Solar UV Radiation. Scientific Reports 8: 13805.

Menachery, V.D.; Dinnon, K.H.; Yount, B.L.; et al. 2020. Trypsin Treatment Unlocks Barrier for Zoonotic Bat Coronavirus Infection. Journal of Virology 94(5): e01774-19.

Miller, F.A.; Silva, C.L.M.; Brandão, T.R.S. 2013. A Review on Ozone-Based Treatments for Fruit and Vegetables Preservation. Food Engineering Reviews 5: 77-106.

Mizzen, L.; Hilton, A.; Cheley, S.; et al. 1985. Attenuation of murine coronavirus infection by ammonium chloride. Virology 142: 378-388

Mullis, L.; Saif, L.J.; Zhang, Y.; et al. 2012a. Stability of bovine coronavirus on lettuce surfaces under household refrigeration conditions. Food Microbiol 30: 180-186.

Mullis, L.; Saif, L.J.; Zhang, Y.B.; et al. 2012b. Stability of bovine coronavirus on lettuce surfaces under household refrigeration conditions. Food Microbiology 30: 180-186.

Nayak, S.L.; Sethi, S.; Sharma, R.R.; et al. 2020. Aqueous ozone controls decay and maintains quality attributes of strawberry (Fragaria $x$ ananassa Duch.). Journal of Food Science and TechnologyMysore 57: 319-326.

Neelakantan, P.; Herrera, D.R.; Pecorari, V.G.A.; et al. 2019. Endotoxin levels after chemomechanical preparation of root canals with sodium hypochlorite or chlorhexidine: a systematic review of clinical trials and meta-analysis. Int Endod J 52: 19-27.

Oliveira, T.C.; Abranches, M.V.; Lana, R.M. 2020. Food (in)security in Brazil in the context of the SARS-CoV2 pandemic. Cad Saude Publica 36: e00055220.

Poletti, V.: Mavilio, F. 2017. Interactions between Retroviruses and the Host Cell Genome. Molecular therapy. Methods \& clinical development 8: 31-41.

Rutala, W.; Weber, D. 2015. Disinfection, Sterilization, and Control of Hospital Waste. Mandell, Douglas, and Bennett's Principles and Practice of Infectious Diseases 2: 3294-3309. 
Schmidt, A.; Wolff, M.; Weber, O. 2005. Coronaviruses with Special Emphasis on First Insights Concerning SARS. Birkhäuser Basel Editorial. 232 pp.

Sharma, V.K.; Graham, N.J.D. 2010. Oxidation of Amino Acids, Peptides and Proteins by Ozone: A Review. Ozone-Science \& Engineering 32: 81-90.

Silva, E.J.N.L.; Prado, M.C.; Soares, D.N.; et al. 2020. The effect of ozone therapy in root canal disinfection: a systematic review. International Endodontic Journal 53: 317-332.

Siqueira, J.F.; Rôças, I.d.N.; Marceliano-Alves, M.F.; et al. 2018. Unprepared root canal surface areas: causes, clinical implications, and therapeutic strategies. Brazilian Oral Research 32(suppl 1): e65.

Sutton, D.; Aldous, E.W.; Warren, C.J.; et al. 2013. Inactivation of the infectivity of two highly pathogenic avian influenza viruses and a virulent Newcastle disease virus by ultraviolet radiation. Avian Pathology 42(6): 566-568.

Tseng, C.-C.; Li, C.-S. 2005. Inactivation of VirusContaining Aerosols by Ultraviolet Germicida Irradiation. Aerosol Science and Technology 39: 1136-1142.

van Doremalen, N.; Schafer, A.; Menachery, V.D.; et al. 2018. SARS-Like Coronavirus WIV1-CoV Does Not Replicate in Egyptian Fruit Bats (Rousettus aegyptiacus). Viruses 10(12): 727

Varga, L.; Szigeti, J. 2016. Use of ozone in the dairy industry: A review. International Journal of Dairy Technology 69: 157-168.

Walker, C.M.; Ko, G. 2007. Effect of Ultraviolet Germicidal Irradiation on Viral Aerosols. Environmental Science \& Technology 41(15): 5460-5465.

Wang, H.; Sikora, P.; Rutgersson, C.; et al. 2018. Differential removal of human pathogenic viruses from sewage by conventional and ozone treatments.
International Journal of Hygiene and Environmental Health 221: 479-488.

Wang, J.; Shen, J.; Ye, D.; et al. 2020. Disinfection technology of hospital wastes and wastewater: Suggestions for disinfection strategy during Coronavirus Disease 2019 (COVID-19) pandemic in China Environmental Pollution 262: 114665.

Weng, J.R.; Lin, C.S.; Lai, H.C.; et al. 2019. Antiviral activity of Sambucus FormosanaNakai ethanol extract and related phenolic acid constituents against human coronavirus NL63. Virus Research 273: 197767.

Wolf, C.; Pavese, A.; von Gunten, U.; et al. 2019. Proxies to monitor the inactivation of viruses by ozone in surface water and wastewater effluent. Water Research 166: 115088.

Woo, P.C.; Huang, Y.; Lau, S.K.; et al. 2010. Coronavirus genomics and bioinformatics analysis. Viruses 2: 1804-1820.

Ye, Y.Y.; Wigginton, K. 2018. Enveloped virus inactivation by UV and chlorine disinfection. Abstracts of Papers of the American Chemical Society 255.

Yuan, Y.; Qi, J.X.; Peng, R.C.; et al. 2020. Molecular Basis of Binding between Middle East Respiratory Syndrome Coronavirus and CD26 from Seven Bat Species. Journal of Virology 94(5): e01387-19.

Zhou, L.; Sun, Y.; Lan, T.; et al. 2019. Retrospective detection and phylogenetic analysis of swine acute diarrhoea syndrome coronavirus in pigs in southern China. Transboundary and Emerging Diseases 66: 687-695.

Zhu, Z.B.; Guo, Y.; Yu, P.; et al. 2019. Chlorine dioxide inhibits the replication of porcine reproductive and respiratory syndrome virus by blocking viral attachment. Infection Genetics and Evolution 67: 7887. 